\title{
Rancang Bangun dan Uji Kinerja Mesin Pemarut Singkong Tipe Silinder untuk Produksi Tepung Tapioka
}

Darma $^{\left.1^{*}\right)}$, Arif Faisol ${ }^{1)}$, Asti Sangaji Dahlia ${ }^{1)}$

1) Jurusan Teknik Pertanian dan Biosistem, Fakultas Teknologi Pertanian Universitas Papua

*darmabond@gmail.com

DOI: https://doi.org/10.21107/rekayasa.v13i3.7071

\begin{abstract}
The development of agroindustry in rural areas has a strategic role because raw materials are commonly produced in the areas. One of the industrial sub-sectors that has bright prospects to develop in rural agroindustries in Indonesia is tapioca flour processing industry. The most important operatiion units in tapioca processing is rasping or grating, which is mechanical disintegration of the tuber cell's wall in order to free the starch granules and it suspended into the water during the extraction process. The objective of this research was to design and test the performance of cylinder type cassava rasping machine. In the experiment, three levels of cylinder rotation speed i.e. $1500 \mathrm{rpm}, 2500 \mathrm{rpm}$ and 3500 and two feeding methods of cassava tuber i.e. perpendicular and pararrel/longitudinal to the cylinder were examined. Results showed that combination of cylinder rotation speed and feeding methods significantly affect the rasping performances. The highest performance was obtained at the condition of cylinder rotation speed of 2500 rpm with feeding method perpendicular to the cylinder. The performance of the machine at the condition were (1) rasping capacity 488,91 $\mathrm{kg} \mathrm{h}^{-1}$, (2) starch percentage 42,28\%, (3) starch loss in waste 7,61\% and (4) rasping effect 84,92\%.
\end{abstract}

Keywords: design, rasping capacity, cylinder rotation speed, cassava rasping machine, tapioca

\section{PENDAHULUAN}

Ubi kayu atau singkong (Manihot esculenta Crantz) merupakan sumber kalori ketiga terpenting di daerah tropis setelah padi dan jagung. Bahkan di Afrika, ubi kayu merupakan tanaman terpenting sebagai sumber kalori (Modeste et al., 2018). Tanaman ini memiliki daya adaptasi yang luas terhadap lingkungan tempat tumbuh dan dapat berproduksi normal pada lahan-lahan marginal sehingga dijadikan sebagai sumber ketahanan pangan (food security) di tingkat keluarga (household). Sekitar $60 \%$ dari total produksi ubi kayu dunia dihasilkan oleh 6 negara yaitu Nigeria, Kongo, Ghana, Brazil, Thailand dan Indonesia. Pada tahun 2016, dari 276.510.000 ton produksi ubi kayu dunia, 163.355.000 ton dihasilkan di ke-6 negara tersebut. Nigeria merupakan Negara produsen terbesar (57.855.000 ton), disusul Thailand (31.161.000 ton), Brazil (21.080.000 ton), Indonesia (20.261.000 ton), Ghana (17.798.000 ton) dan Kongo (15.200.000 ton) (FAO, 2018).

\section{Article History:}

Received: April, 13 ${ }^{\text {th }}$ 2020; Accepted: Dec, $11^{\text {th }} 2020$ Rekayasa ISSN: 2502-5325 has been Accredited by Ristekdikti (Arjuna) Decree: No. 23/E/KPT/2019 August 8th, 2019 effective until 2023
Ubi kayu dibudidayakan di semua provinsi termasuk Papua dan Papua Barat dan produksinya cenderung meningkat dari tahun ke tahun. Peningkatan produksi ubi kayu perlu dibarengi dengan teknologi pengolahan yang dapat meningkatkan diversifikasi dan nilai tambah produk ubi kayu. Umbi ubi kayu dapat diolah menjadi aneka produk seperti aneka kue, keripik singkong, dan pati singkong (tepung tapioka). Ubi kayu memiliki kandungan karbohidrat yang cukup tinggi yaitu 29\%. (Pusat Data dan Sistem Informasi Pertanian, 2016). Pengembangan industri berbasis ubi kayu perlu terus digalakkan karena merupakan komoditas yang memiliki potensi ekonomi tinggi.

Salah satu sub-sektor industri yang memiliki prospek cerah untuk dikembangkan dalam agroindustri pedesaan di Indonesia, termasuk di Papua dan Papua Barat yaitu industri tepung tapioka karena didukung oleh ketersediaan bahan baku yang memadai. Industri tepung tapioka merupakan industri yang memiliki

\section{Cite this as:}

Darma, Faisol, A \& Dahlia, A.S. (2020). Rancang Bangun dan Uji Kinerja Mesin Pemarut Singkong Tipe Silinder untuk Produksi Tepung Tapioka. Rekayasa, 13 (3), 254-262. doi: https://doi.org/10.21107/rekayasa.v13i3.7071

(c) 2020 Darma, Arif Faisol, Astri Sangaji Dahlia 
peluang dan prospek pengembangan yang baik untuk memenuhi permintaan pasar. Industri tepung tapioka termasuk industri hilir, dimana industri ini melakukan proses pengolahan dari bahan baku singkong menjadi tepung tapioka. Permintaan tapioka di Indonesia cenderung terus meningkat. Peningkatan tersebut karena terjadi peningkatan jumlah industri makanan dan non makanan, industri tekstil, kertas, sorbitol, dan lain sebagainya yang menggunakan tepung tapioka sebagai bahan baku industrinya (Kementerian Tenaga Kerja, 2016).

Proses pengolahan tapioka pada dasarnya adalah mengekstrak pati yang terkandung dalam ubi kayu. Proses dasar ekstraksi pati ubi kayu adalah pengupasan (peeling), pencucian ubi, pemarutan, ekstraksi, pengendapan pati, pencucian (pemutihan), dan pengeringan. Setiap tahapan proses saling terkait satu sama lain, dimana keberhasilan masing-masing tahapan proses akan mempengaruhi keberhasilan proses secara keseluruhan. Untuk mencapai keberhasilan proses produksi tapioka secara menyeluruh, maka masing-masing tahapan proses perlu diawasi agar sesuai dengan kondisi yang diharapkan.

Salah satu unit operasi terpenting dalam proses pengolahan tapioka adalah pemarutan yaitu penghancuran secara mekanis damaging umbi segar sehingga granula pati dapat dipisahkan dari komponen lainnya pada proses ekstraksi. Pemarutan dapat dilakukan secara manual atau menggunakan mesin tergantung pada kapasitas produksi yang ingin dicapai. Dengan pemarutan umbi segar, dinding-dinding sel robek dan keseluruhan massa umbi menjadi berbentuk bubur (slurry), namun tidak semua granula pati terbebas. Persentase pati yang terbebas (freed starch) bervariasi antara 70\%$90 \%$ tergantung derajat kehalusan umbi hasil parutan. Salah satu factor yang mempengaruhi effisiensi dan efektivitas operasi pemarutan adalah mesin pemarut yang digunakan. Pada umumnya ada 2 tipe mesin pemarut yang digunakan oleh para produsen tapioka di seluruh penjuru dunia yaitu tipe silinder dan tipe piringan. Di India terdapat sekitar $600 \quad-700$ pabrik pengolahan tapioka berbagai skala, kecil, menengah dan besar, pada umumnya menggunakan mesin parut tipe silinder (Sajev et al., 2012). Demikian pula halnya dengan di negara-negara afrika (Department of Agriculture,
Forestry and Fisheries Republic of South Africa, 2010), Thailand (Yimmongkol, 2009) dan Indonesia pada umumnya menggunakan mesin parut tipe silinder. Di Vietnam, pabrik pengolahan tapioca skala kecil sebagian menggunakan tipe piringan namun sebagian besar menggunakan tipe silinder (Guillaume et al., 2008).

Bagian fungsional mesin pemarut tipe silinder berupa silinder (drum) yang pada permukaan kelilingnya dipasangi gigi-gigi tajam. Kinerja pemarutan (rasping effect) sangat tergantung pada dimensi silinder dan karakteristik gigigerigi. Dengan demikian, kapasitas pemarutan dan Jumlah maksimum pati yang bisa terekstrak tergantung pada dimensi silinder dan karakteristik gigi-gerigi. Nanda et al., (2004) menggunakan bilah gigi gergaji yang dipasang pada silinder dengan kapasitas 360-381 kg/jam. Sajev et al., (2012) mengembangkan mesin parut dengan komponen silinder dari pipa besi berdiameter $21 \mathrm{~cm}$, panjang $36 \mathrm{~cm}$ menggunakan bilah gigi gergaji dengan kerapatan 10 gigi per inch. Mesin pemarut tipe Jahn yang umum digunakan pabrik skala menengah dan besar di India, menggunakan silinder besi dengan bilah gigi gergaji, bilah dipasang secara longitudinal pada permukaan keliling silinder, jarak antar bilah $10 \mathrm{~mm}$ (Sheriff et al., 2005).

Mesin pemarut yang umum digunakan pabrik skala kecil di Vietnam, komponen silinder dari bahan kayu berdiameter $23 \mathrm{~cm}$ dan panjang 31 $\mathrm{cm}$, gigi dari kawat halus dengan tinggi $3 \mathrm{~mm}$ (Guillaume et al., 2008). Industri pengolahan tapioca oleh IKM di Indonesia sebagian besar menggunakan tipe silinder dengan karakteristik gigi yang bervariasi, ada yang menggunakan jarum, paku, kawat dan sebagian menggunakan tipe jahn. Wilson et al., (2019) dan Sardi (2013) mengembangkan mesin parut dengan silinder dari bahan kayu berdiameter $12 \mathrm{~cm}$, panjang 15 $\mathrm{cm}$ dengan gigi dari kawat stainless steel berdiameter $1,5 \mathrm{~mm}$ dan tinggi $5 \mathrm{~mm}$.

Hasil penelitian - penelitian terdahulu menunjukkan karakteristik gigi parut mempengaruhi kinerja mesin parut singkong. Beberapa faktor karakteristik gigi parut yang mempengaruhi kinerja mesin antara lain bentuk geometri, diameter, jarak antar gigi, pola susunan, dan kecepatan linier. Tujuan penelitian ini adalah merancang dan menguji kinerja mesin 
parut singkong tipe silinder untuk produksi tapioka dengan fokus utama mengkaji pengaruh kecepatan putar silinder dan metode pengumpanan umbi terhadap kinerja pemarutan.

\section{METODE PENELITIAN}

\section{Peralatan dan Bahan}

Peralatan yang digunakan terdiri dari (1) peralatan untuk pembuatan konstruksi mesin parut singkong yaitu berupa peralatan perbengkelan standard seperti mesin bubut, mesin las listrik, gurinda, saw mill, bor listrik, ragum, meteran, tang, dan berbagai ukuran kunci serta obeng. (2) peralatan untuk pengujian kinerja yaitu: tacho meter digital, timbangan duduk digital, stop watch, saringan pati manual 120 mesh, blender, pisau dapur, parang, wadah penampung hasil parutan dan pati, karung plastic dan terpal.

Bahan yang digunakan untuk pembuatan konstruksi mesin parut sagu adalah besi siku 5 $\mathrm{cm} \times 5 \mathrm{~cm} \times 0,5 \mathrm{~cm}$, plat stainless steel SS 304 tebal $2 \mathrm{~mm}$, poros as SS $201 \varnothing$ 25,5 mm, kawat SS $201 \varnothing 3$ mm, bearing unit UCP 205, motor bensin Honda GX 160, 5,5 hp, pulley $\varnothing 7,62 \mathrm{~cm}$, V-belt A-49, silinder $\varnothing 15 \mathrm{~cm}$ panjang $22 \mathrm{~cm}$ dari kayu lamtoro, engsel bubut $\varnothing 12 \mathrm{~mm}$. Bahan untuk uji kinerja berupa umbi singkong segar dan air bersihempulur batang sagu dan air bersih untuk ekstraksi pati.

\section{Rancangan Fungsional}

Mesin pemarut singkong ini terdiri dari 6 komponen utama yaitu: (1) Silinder penghancur, merupakan komponen fungsional (process system) dari mesin pemarut singkong, berfungsi untuk menghancurkan umbi singkong segar menjadi partikel-partikel yang cukup halus sehingga pati yang terdapat dalam sel dapat dipisahkan pada proses lebih lanjut yaitu proses ekstraksi. Dengan berputarnya silinder yang telah diberi gigi-gerigi berupa kawat stainless steel maka proses pemarutan akan berlangsung manakala diberikan input berupa umbi singkong. Pemarutan dilakukan dengan menempelkan dan mendorong umbi ke silinder yang sedang berputar; (2) Rangka (frame), merupakan bagian structural utama yang menyatukan dan sekaligus merupakan dudukan bagi komponen-komponen lainnya; (3) Tenaga penggerak (power), berupa four-stroke gasoline engine 5,5 hp (honda GX 160T), berfungsi sebagai sumber tebaga putar bagi silinder penghancur; (4) Hopper sebagai landasan pemasukan dan mengarahkan umbi singkong ke silinder penghancur; (5) Komponen transmisi daya, berfungsi untuk menyalurkan daya dari motor penggerak ke silinder penghancur. Metode transmisi menggunakan pulley dan V-belt, baik pulley motor (driver pulley) maupun pulley silinder (driven pulley) keduanya berdiameter 7,62 cm (type A2) dan (6) Saluran pengeluaran (unloading), sebagai tempat jatuhnya hasil parutan untuk selanjutnya disalurkan ke wadah penampungan. Untuk mencegah hasil parutan tersebar kemana-mana dibuat penutup silinder baik pada bagian atas maupun pada bagian bawah.

\section{Rancangan Struktural}

Pemilihan bahan untuk pembuatan konstruksi mesin didasarkan pada ketersediaan bahanbahan di pasaran, dan daya tahan bahan tersebut saat digunakan. Khusus untuk bagianbagian yang kontak langsung dengan umbi saat pengolahan digunakan bahan yang sesuai dengan standard berkriteria food grade (stainless steel SS 304).

Dari segi struktural, konstruksi keseluruhan (overall structure) dari mesin pemarut singkong ini ditampilkan pada Gambar 1. Sebagaimana telah diuraikan di atas dan diperlihatkan pada Gambar 1. Mesin ini terdiri dari beberapa bagian utama yaitu:

1. Silinder penghncur, berupa silinder padat (solid cylinder) terbuat dari kayu lamtoro ukuran panjang $22 \mathrm{~cm}$ dan diameter $15 \mathrm{~cm}$. Pada pusat silinder dipasangi poros berdiameter 2,54 $\mathrm{cm}$, dari bahan anti karat SS 201. Di salah satu ujung poros silinder terdapat pulley berdiameter 7,62 cm (tipe A2) dari bahan besi cor. Gigi parut berupa kawat stainless steel SS 201 berdiameter $1 \mathrm{~mm}$, dipasang pada permukaan keliling silinder dengan jarak antar gigi $5 \mathrm{~mm} \times 5 \mathrm{~mm}$ dan tinggi $1 \mathrm{~mm}$ dari permukaan silinder. Pengaturan gigi parut dibuat sedemikian rupa sehingga pada waktu proses pemarutan berlangsung, semua gigi bekerja secara efektif dan tidak ada bagian umbi yang tidak terparut (Darma et al., 2014). Profil silinder penghancur disajikan pada Gambar 2. 
2. Rangka (frame), dibuat dari besi siku berukuran $5 \mathrm{~cm} \times 5 \mathrm{~cm} \times 0.5 \mathrm{~cm}$. Ukuran/dimensi rangka adalah tinggi $85 \mathrm{~cm}$, lebar bawah 45,5 cm, lebar atas $36 \mathrm{~cm}$, panjang bawah 55,8 cm, panjang atas $55,8 \mathrm{~cm}$.

3.Tenaga penggerak (power), menggunakan motor bakar (engine) 4 tak merek honda GX 160T, 5.5 HP.(4,1 kW), putaran maksimum 3600 rpm. Pada poros motor dipasangi pulley berdiameter 7,62 cm (tipe A2) dari bahan besi cor. Pada dudukan motor dibuat jalur memanjang yang dimaksudkan untuk pengaturan posisi pulley motor sejajar dengan pulley silinder sebelum dikunci.

4. Bagian pemasukan bahan (hopper), terbuat dari plat besi anti karat SS 304 tebal 2 mm, sisi depan dibuat miring membentuk sudut $45^{\circ}$ terhadap bidang horizontal, sedangkan ketiga sisi lainnya tegak lurus dengan rangka. Pada sebagian bagian atas dipasangi penutup yang dipasang ke hopper menggunakan engsel sehingga mudah dibuka dan ditutup.

5.Komponen transmisi daya, mengggunakan pulley dan v-belt. Daya dari motor penggerak disalurkan oleh driver pulley yang terpasang pada poros motor ke driven pulley yang terpasang pada poros silinder melalui v-belt. Diameter pulley pada poros motor sama dengan diameter pada pulley silinder yaitu 7,62 $\mathrm{cm}$ (tipe A2), kedua pulley dihubungkan secara langsun menggunakan V-belt A-48 (2 buah) tanpa dilengkapi dengan system kopling. Pengaturan tegangan (tension) v-belt dilakukan dengan menggeser posisi motor penggerak kea rah depan/belakang.

6. Saluran pengeluaran (unloading), terbuat dari plat besi anti karat SS 304 tebal 2 mm, pada kedua sisinya ditekuk membentuk sudut $90^{\circ}$. Ukuran lebar unloading sama dengan lebar hopper dan membentuk sudut kemiringan $40^{\circ}$ dengan bidang horizontal.

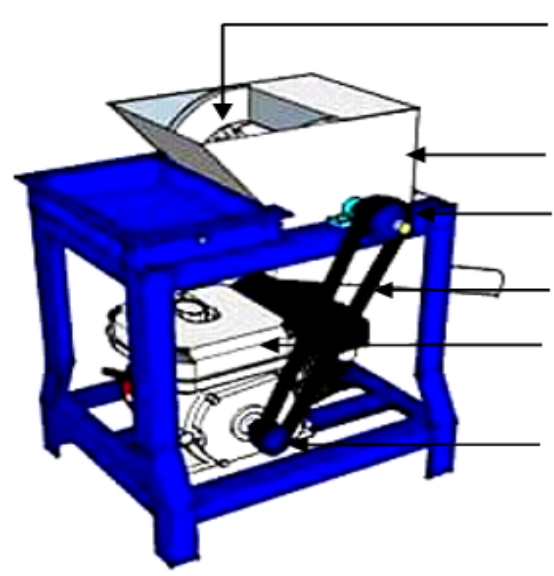

Silinder penghancur

Gambar 1. Konstruksi dan Bagian-Bagian Mesin Parut Singkong untuk Produksi Tapioka
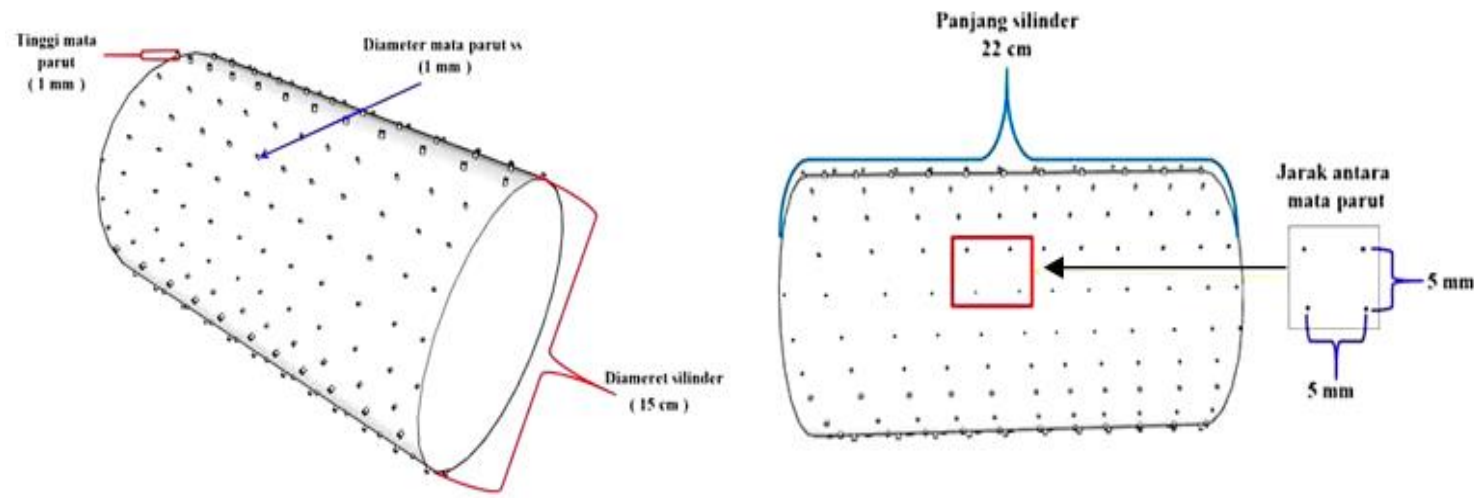

Gambar 2. Profil dan Karakteristik Komponen Silinder Penghancur 


\section{Prosedur Pengujian Kinerja dan Analisis Data}

Sebelum dilakukan pengujian kinerja pemarutan, terlebih dahulu dilakukan uji fungsional untuk mengetahui apakah semua komponen berfungsi dengan baik dan secara keseluruhan mesin berfungsi secara layak (work properly). Prosedur pengujian kinerja mesin parut diawali dengan pengupasan umbi singkong, pencucian, pemarutan umbi singkong, ekstraksi pati dan pengendapan pati. Bagan alir prosedur pengujian kinerja mesin ditampilkan pada Gambar 3. Pengujian dilakukan pada 2 faktor variable bebas (independent variable) yaitu (1) kecepatan putar silinder dan (2) metode pengumpanan bahan ke silinder penghancur. Kecepatan putar silinder terdiri dari 3 level yaitu 1500 rpm (V1), 2500 rpm (V2), dan 3500 rpm (V3), dan metode pengumpanan bahan ada 2 cara yaitu tegak lurus terhadap silinder/end on direction (M1) dan sejajar/longitudinal dengan silinder (M2).

Pengaturan kecepatan putar silinder dilakukan dengan penyetelan tuas gas (thortle) pada motor penggerak hingga dicapai putaran yang diinginkan. Dengan demikin terdapat 6 kombinasi perlakuan kecepatan putar silinder dan metode pengumpanan bahan yaitu $V_{1} M_{1}$ $V_{1} M_{2}, V_{2} M_{1}, V_{2} M_{2}, V_{3} M_{1}, V_{3} M_{2}$. Masing-masing perlakuan terdiri dari 3 ulangan, sehingga berjumlah 18 unit percobaan. Evaluasi kinerja dari masing-masing perlakuan dilakukan dengan mengukur parameter: (1) Kapasitas pemarutan, (2) Rendemen pati, (3) Kehilangan pati pada ampas (starch losses) dan (4) Effektivitas pemarutan (rasping effect). Data hasil pengukuran diolah dengan analisis varian (ANOVA) untuk menentukan pengaruh variabel bebas (perlakuan) terhadap variabel terikat (dependent variable) dan dilanjutkan dengan uji beda nyata terkecil (LSD) jika ada perbedaan pengaruh yang nyata antar perlakuan.

Prosedur pengujian untuk masing-masing parameter adalah sebagai berikut:

- Kapasitas Pemarutan

Keterangan:

$$
K P=\frac{m U(k g)}{T(j a m)}
$$

$\mathrm{KP}$ : kapasitas pemarutan $(\mathrm{kg} / \mathrm{jam})$

$\mathrm{mU}$ : massa umbi yang diparut $(\mathrm{kg})$

$\mathrm{T}$ : waktu pemarutan (jam)
Rendeman Pati (\%)

Keterangan :

$$
R D=\frac{m P(k g)}{m U(k g)} \times 100 \%
$$

$\mathrm{RD}$ : rendemen pati (\%)

$\mathrm{mP}$ : massa pati hasil ekstraksi $(\mathrm{kg})$

$\mathrm{mU}$ : massa umbi yang diparut $(\mathrm{kg})$

- Kehilangan Pati dalam Ampas (\%)

$$
P A=\frac{m P A(k g)}{m A(k g)} \times 100 \%
$$

\section{Keterangan:}

PA : presentase pada ampas $(\mathrm{kg})$

MPa : massa pati dalam ampas $(\mathrm{kg})$

$\mathrm{mA}$ : massa ampas $(\mathrm{kg})$

- Effektivitas pemarutan (rasping effect) (\%)

Merupakan perbandingan antara rendemen pati dengan kandungan pati total pada umbi, dihitung menggunakan persamaan :

$$
E P=\frac{R D(\%)}{K P T(\%)} \times 100 \%
$$

Keterangan:

EP : efektivitas pemarutan (\%)

$\mathrm{RD}$ : rendemen pati (\%)

KPT : Kandungan pati total (basis basah, wb) (\%)

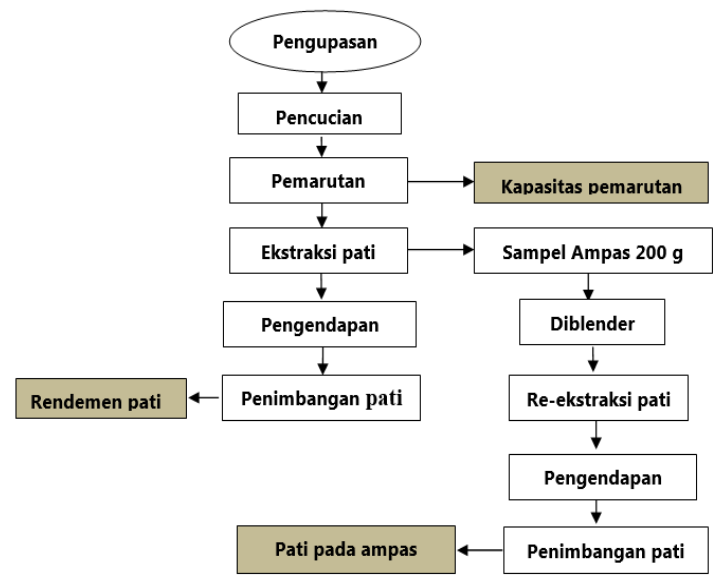

Gambar 3. Bagan Alir Prosedur Uji Kinerja Mesin Pemarut Singkong

\section{HASIL DAN PEMBAHASAN \\ Uji Kinerja Kapasitas Pemarutan}

Pemarutan bertujuan menghancurkan/ merusak dinding sel sehingga granula pati yang terdapat dalam sel-sel jaringan umbi menjadi terbebas (freed or loosen starch) sehingga bisa bisa tersuspensi ke dalam air pada saat ekstraksi. 
Tabel 1. Rata-Rata Kapasitas Pemarutan, Rendemen Pati, Kehilangan Pati pada Ampas dan Efektivitas Pemarutan dari Berbagai Kombinasi Perlakuan yang Diuji

\begin{tabular}{ccccc}
\hline Perlakuan & $\begin{array}{c}\text { Kapasitas pemarutan } \\
(\mathrm{kg} / \text { jam) }\end{array}$ & $\begin{array}{c}\text { Rendemen pati } \\
\text { basah (\%) }\end{array}$ & $\begin{array}{c}\text { Kehilangan pati } \\
\text { pada ampas (\%) }\end{array}$ & $\begin{array}{c}\text { Efektivitas } \\
\text { pemarutan (\%) }\end{array}$ \\
\hline V1M1 & $281,94^{\mathrm{a}}$ & $22,18^{\mathrm{a}}$ & $14,57^{\text {tn }}$ & $60,53^{\mathrm{a}}$ \\
V1M2 & $508,79^{\mathrm{b}}$ & $38,70^{\mathrm{b}}$ & $16,17^{\text {tn }}$ & $70,60^{\mathrm{c}}$ \\
V2M1 & $488,91^{\mathrm{b}}$ & $42,28^{\mathrm{b}}$ & $7,61^{\mathrm{tn}}$ & $84,92^{\mathrm{d}}$ \\
V2M2 & $233,10^{\mathrm{a}}$ & $35,71^{\mathrm{a}}$ & $14,73^{\text {tn }}$ & $70,40^{\mathrm{b}}$ \\
V3M1 & $273,11^{\mathrm{a}}$ & $43,36^{\mathrm{b}}$ & $11,77^{\text {tn }}$ & $79,32^{\mathrm{cd}}$ \\
V3M2 & $315,61^{\mathrm{a}}$ & $32,24^{\mathrm{a}}$ & $8,90^{\text {tn }}$ & $77,91^{\mathrm{d}}$ \\
\hline
\end{tabular}

Keteragan:

V1: kecepatan putar silinder 1500 rpm, V2: 2500 rpm dan V3: 3500 rpm.

M1: metode pengumpanan bahan tegak lurus terhadap silinder, dan M2: sejajar dengan selinder

Angka dalam kolom sama yang diikuti oleh huruf yang sama tidak berbeda nyata menurut uji BNJ pada $\alpha 5 \%$

Berdasarkan hasil analisis sidik ragam menunjukan bahwa kombinasi perlakuan kecepatan putar silinder dan metode pengumpanan bahan berpengaruh nyata terhadap kapasitas pemarutan. Pada Tabel 1 disajikan hasil uji kinerja pemarutan pada berbagai kombinasi perlakuan kecepatan putar silinder dan metode pengumpanan bahan.

Pada Tabel 1 terlihat bahwa kombinasi perlakuan V1M2 memiiki kapasitas parut tertinggi $(508.79 \mathrm{~kg} / \mathrm{jam})$ yang tidak berbeda nyata dengan perlakuan V2M1 (488.91 kg/jam) dan kapasitas pemarutan terrendah terdapat pada perllakuan V2M2 $(233.10 \mathrm{~kg} / \mathrm{jam})$ yang tidak berbeda nyata dengan perlakuan V3M1 (273.11 kg/jam), V1M1 (281.94 kg/jam) dan V3M2 (315.61 kg/jam). Terlihat juga dari Tabel 1 bahwa untuk factor metode pengumpanan bahan tegak lurus terhadap silinder, terjadi peningkatan kapasitas pemarutan dari $1500 \mathrm{rpm}$ ke 2500 rpm namun peningkatan rpm lebih lanjut yaitu dari 2500 rpm ke 3500 rpm terjadi penurunan kapasitas pemarutan. Sedangkan untuk arah pengumpanan bahan sejajar terhadap silinder ada kecenderungan penurunan kapasitas dengan adanya peningkatan rpm silinder. Semakin tinggi rpm semakin tinggi kapasitas pemarutan karena frekuensi memarut/memotong untuk setiap gigi semakin tinggi, selama kebutuhan gaya dari sumber tenaga penggerak untuk memarut bahan masih mencukupi. Sebaliknya kalau kebutuhan gaya dari sumber tenaga penggerak tidak mencukupi maka peningkatan rpm lebih lanjut menurunkan kapasitas pemarutan.

Hal ini yang menyebabkan kapasitas pemarutan tertinggi pada perlakuan V1M2 dan terendah pada perlakuan V2M2. Hasil penelitian ini konsisten dengan hasil penelitian Darma et al., (2017) yang melaporkan bahwa kapasitas pemarutan mesin parut sagu tipe silinder meningkat dari 1500 rpm ke 2250 rpm kemudian peningkatan lebih lanjut yaitu ke 3000 rpm kapasitas pemarutan menurun. Hasil penelitian. Darma et al (2014) juga melaporkan bahwa dari rpm 745 sampai 2000 rpm terjadi peningkatan kapasitas parut, kemudian peningkatan lebih tinggi sampai 3725 rpm mengakibatkan penurunan kapasitas parut. Hasil penelitian ini juga sejalan dengan hasil penelitian Rumere (2019) yang melaporkan bahwa kapasitas pemarutan mesin parut sagu tipe silinder tanpa pengupasan kulit meningkat dari $1500 \mathrm{rpm}$ ke 2000 rpm kemudian menurun saat ditingkatkan lebih lanjut ke $2500 \mathrm{rpm}$.

Kapasitas pemarutan tertinggi yang dihasilkan dari penelitian ini ( $508.79 \mathrm{~kg} / \mathrm{jam})$ lebih tinggi dibandingkan dengan kapasitas pemarutan prototype mesin parut singkong pada penelitian sebelumnya yang di lakukan oleh Aman et al, (2019) yang memiliki kapasitas pemarutan tertinggi yaitu $(448,24 \mathrm{~kg} / \mathrm{jam})$ dan Nanda et al,. (2004) yang mempunyai kapasitas berkisar 360-385 kg/jam. Namun demikian hasil penelitian ini lebih rendah kapasitas pemarutannya di bandingkan dengan hasil penelitian Oriaku et al., (2015) dan Sajeev et al, (2012) yang menghasilkan kapasitas pemarutan berturut-turut 730,58 kg/jam dan 900-1000 $\mathrm{kg} / \mathrm{jam}$. Guillaume et al., (2008) melaporkan, kapasitas pemarutan di beberapa industry pengolahan tapioca di Vietnam bagian utara $1.053 \mathrm{~kg} / \mathrm{jam}$. Secara umum ada 2 faktor yang mempengaruhi kapasitas pemarutan yaitu factor mesin (tipe, besar daya yang digunakan, dimensi 
silinder dan kondisi geometry gigi parut) dan sifat mekanik bahan yang diproses. Menurut Sitkey (1986), sifat-sifat mekanik bahan tergantung pada tahap pertumbuhan (growing stage), kadar air dan posisinya dari arah pangkal atau dari arah ujung.

\section{Rendemen Pati}

Hasil parutan umbi (Gambar 4) diekstrak patinya secara manual hingga semua kandungan pati terekstrak, yang ditandai dengan air hasil perasan jernih lalu pati hasil ekstraksi ditimbang. Rendemen pati basah adalah rasio massa pati yang diperoleh dari hasil ekstraksi terhadap massa hasil parutan umbi singkong. Rendemen pati basah pada penelitian ini dihitung dengan mengekstraksi $7 \mathrm{~kg}$ singkong yang telah diparut untuk setiap unit percobaan.
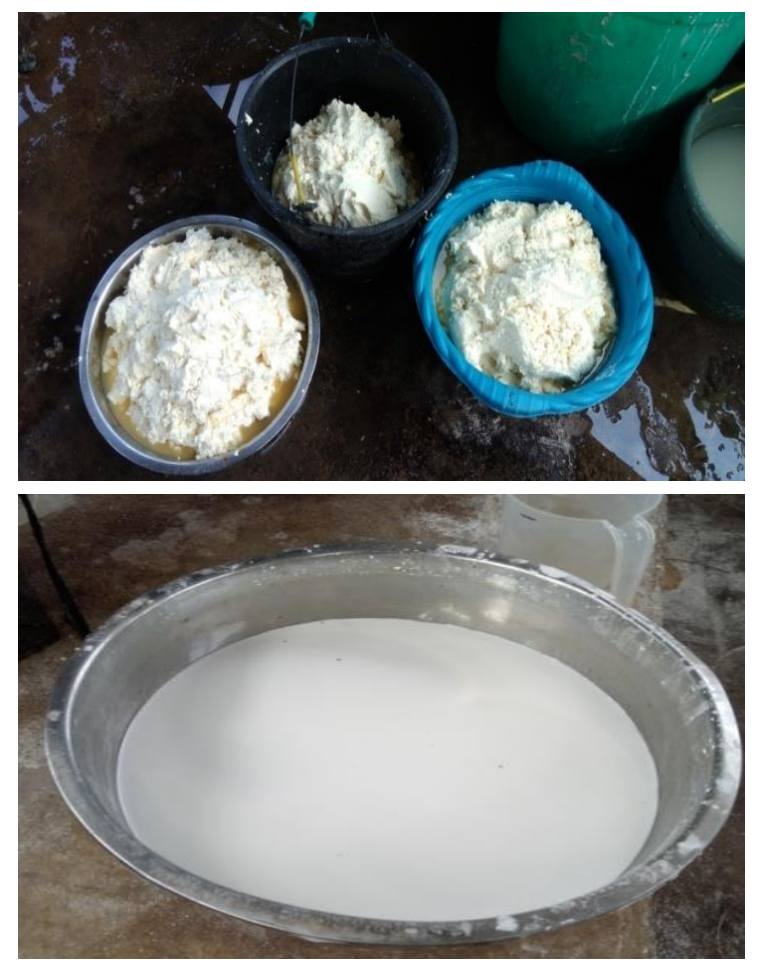

Gambar 4. Hasil Parutan Umbi (Kiri) dan Pati Hasil Ekstraksi (Kanan)

Hasil analisis sidik ragam menunjukan bahwa kombinasi perlakuan berpengaruh nyata terhadap rendemen pati. Sebagaimana telah terlihat pada tabel 1 rata-rata rendemen pati tertinggi diperoleh pada kombinasi peralakuan V3M1 (43,36\%) yang tidak berbeda nyata dengan V2M1 (42,28\%), dan V1M2 (38,70\%). Rendemen pati terendah diperoleh pada perlakuan V1M1 $(22,18 \%)$, namun tidak berbeda nyata dengan perlakuan V2M2 (35,71\%), dan V3M2 (32,24\%). Rendemen pati yang tinggi menunjukan bahwa partikel hasil parutan lebih halus. Semakin halus partikel singkong hasil parutan maka semakin besar persentase pati yang terekstrak. Hasil penelitian ini konsisten dengan hasil penelitian Wilson et al, (2019) dengan rendemen pati antara 45,66\%-46,67\%. Hasil penelitian Sajev et al., (2012) memperoleh rendemen pati kering $18,98 \%$ (setara dengan rendemen pati basah $37,96 \%$. Hasil pati kering dari berbagai industri pengolahan skala kecil di Vietnam bagian utara bervariasi antara 25-27\% (Guillaume et al., 2008). Industri pengolahan tapioca IKM Kharisma di SP 5 Manokwari menghasilkan rendemen pati basah $39,62 \%$ (rendemen pati kering 23,91 \%) (Frides, 2020).

Hasil penelitian Mustafa (2015) menghasilkan rendemen pati basah 29,55 \% dengan rendemen pati kering $18,74 \%$. Hasil pati suatu industri tapioca dari berbagai negara sangat bervariasi, mulai dari $17 \%$ di Pantai Gading, $21 \%$ di Brazil sampai $25 \%$ di Thailand tergantung pada teknologi yang digunakan (Guillaume et al., 2010). Rendemen pati selain dipengaruhi mesin dan teknik pengolahan, juga dipengaruhi jenis dan umur panen yang optimal.

\section{Kehilangan Pati pada Ampas (Starch Losses)}

Hasil analisis keragaman menunjukan bahwa kombinasi perlakuan tidak berpengaruh nyata terhadap kehilangan pati pada ampas. Walaupun demikian, dari Tabel 1 terlihat bahwa ada kecenderungan penurunan kehilangan pati pada ampas dengan adanya peningkatan rpm silinder penghancur. Hal ini mengindikasikan bahwa pada rpm yang lebih tinggi menghasilkan hancuran umbi berukuran lebih halus sehingga pati yang tidak terbebas (unfreed starch) lebih sedikit.

Hasil ini didukung oleh hasil penelitian Sajeev et al., (2012) yang mengukur modulus kehalusan (finess modulus) dan ukuran partikel (particle size) pada berbagai rpm silinder menunjukkan bahwa modulus kehalusan dan ukuran partikel menurun dengan meningkatnya rpm silinder. Kisaran kehilangan pati pada ampas yang diperoleh pada penelitian ini antara 8,90\% - 16,17\% konsisten dengan hasil penelitian Wilson et al., (2019) yang memperoleh kehilangan pati pada ampas 10,73 $\%-14 \%$. 


\section{Efektivitas Pemarutan (Rasping Effect)}

Berdasarkian dari Tabel 1, memperlihatkan bahwa kombinasi perlakuan berpengaruh nyata terhadap rasping effect. Nilai tertinggi diperoleh pada perlakuan V2M1 (84,92 \%) yang tidak berbeda nyata dengan V3M1 (79,32 \%) dan V3M2 (77,91 \%) dan terendah pada V1M1 (60,53 $\%)$ yang berbeda nyata dengan semua perlakuan lainnya. Hasil penelitian ini sejalan dengan hasil penelitian Sajeev et al., (2012) memperoleh rasping effect $83,39 \%$. Hasil ini juga mendukung hasil penelitian Wilson et al., (2019) dan Guillaume et al., (2008) yang menghasilkan rasping effect berturut-turut antara 76,53 \% $81,30 \%$ dan $85,0 \%-85,1 \%$.

Sajeev dan Balagopalan (2005) dan Nanda et al., (2004) memperoleh rasping effect berturutturut $84,20 \%$ dan $76-79 \%$. Department of Agriculture, forestry and fisheries republic of South Africa (2010) melaporkan bahwa rasping effect industry pengolahan tapioca di Africa antara $70-90 \%$. Rasping effect dipengaruhi terutama oleh mekanisme penghancuran yang digunakan pada suatu mesin.

\section{KESIMPULAN DAN SARAN \\ Kesimpulan}

Mesin pemarut singkong untuk ekstraksi pati yang didesain pada penelitian ini berfungsi baik dengan kinerja yang tinggi. Dari hasil pengujian menunjukan bahwa kombinasi perlakuan kecepatan putar silinder dan metode pengumpanan umbi berpengaruh nyata terhadap kinerja pemarutan. Kinerja terbaik diperoleh pada kondisi kecepatan putar silinder 2500 rpm dengan metode pengumpanan bahan umbi end on direction (tegak lurus terhadap silinder). Kinerja mesin pemarut pada kondisi tesebut adalah (1) kapasitas pemarutan 488,91 $\mathrm{kg} / \mathrm{jam}$, (2) rendemen pati $42,28 \%$, kehilangan pati pada ampas $7,61 \%$ dan (4) rasping effect $84,92 \%$.

\section{UCAPAN TERIMA KASIH}

Penulis menyampaikan apresiasi dan terima kasih kepada Kementerian Riset, Teknologi dan Pendidikan Tinggi c.q. Direktorat Penelitian dan Pengabdian Kepada Masyarakat atas dukungan dana untuk penelitian ini.

\section{DAFTAR PUSTAKA}

Aman, W.P., Darma, M. K. Roreng dan Sardi. (2019). Rancangan dan Kinerja Teknis Mesin Parut Singkng Tipe Silinder Bertenaga Motor Bakar. REKAYASA: Journal of Science and Technogy. Vol. 12 (1):59-65.

Cliver, F. (2020). Analisis Neraca Massa Industri Tapioka pada Industri Kecil Menengah Kharisma di Distrik Masni, Kabupaten Manokwari. Skripsi Sarjana Fakutas Tekongi Pertanian Universitas Papua. Manokwari.

Darma, Xiulun WANG, Koji KITO. (2014). Development of Cylinder Type Sagp Rasper for Improving Rasping Performance. International Agricultural Engginering Journal Sago (IAEJ). Vol. 23, No. 3:31-40.

Darma, B. Santoso, Reniana. (2017). Development of Cylinder Type Sago Rasping Machine Using Pointed Teeth. International Journal of Engineering and Technology (IJET-IJENS) Vol. 17, No.01: 2472-2481.

Darma, B. Santoso, M. A. Arbianto dan B. Mangallo. (2019). Effect of Cylinder Rotation Speed and Teeth Density on Power Requirement and Specific Energy Consumption of Sago Rasping Machine. International Journal of Engineering and Technology (IJET-IJENS). Vol. 19, No.04: 1622.

Department of Agriculture, Forestry and Fisheries Republic of South Africa. (2010). Cassava: Production Gudeline. Directorate Agricultural Information Services. Pretoria.

FAO. (2018). Food Outlook - Biannual Report on Global Food Markets - November 2018. Rome.

Kementerian Ketenagakerjaan Republik Indonesia. 2016. Lampiran Keputusan Menteri Ketenagakerjaan Republik Indonesi No. 104 Tentang Penetapan Standar Kompetensi Kerja Nasional Indonesia Kategori Industri Pengolahan Golongan Pokok Industri Makanan Bidang Pengolahan Tapioka. Menteri Ketenagakerjaan RI. Jakarta. 
Modeste, K. K., M. Adolphe, N. Boni, K. Edmond and K. Camille. (2018). Status of Cassava (Manihot Esculenta Crantz) in Côte d'Ivoire: From Production to Consumption and Evaluation of Technology Adoption. European Scientific Journal. Vol.14, No.9: 285-299.

Mustafa, A. (2015). Analisis Proses Pembuatan Pati Ubi kayu (Tapioka) Berbasis Neraca Massa. Jurnal Agrointek Vol.9, No.2: 127133.

Nanda, S.K., P. Hemasankari dan J.T. Sheriff. (2004). Development of a Primary Rasper for Stach Extractin from Tuber crop in: Proceedings of National Seminar Root and Tuber Crops (NRSTC I), 29-31 October 2004. Regional Centre of Central Tuber Crops Research Institute, Bhubaneswar, Orissa, India.

Oriaku, E.C., C.N. Agulanna, E.N. Ossai, J.O. Odenigbo dan U.L. Adizue. (2015). Design and Performance Evaluation of a Double Action Cassava Grating Machine. Journal of Emerging Trends in Engineering and Applied Sciences (JETEAS). Vol.6 (3):196203.

Rumere, C. S. (2019). Pengembangan Desain Mesin Parut Sagu (Metroxilon sp.) Tipe Silinder Bertenaga Motor Bakar Bensin Dengan Sistem Pemarutan Tanpa Pengupasan Kulit Batang. Skripsi Fakutas
Tekongi Pertanian Universitas Papua. Manokwari.

Sardi. (2013). Desain dan uji kinerja alat dan mesin pemarut singkong (Manihot Utilissima Phol) bertenaga motor bakar. Universitas Negeri Papua Manokwari.

Sajeev, M.S., S.K. Nanda and J.T. Sheriff. (2012). An Efficient Blade Type Rasper for Cassava Starch Extraction. Journal of Root Crops. Vol.38 (2):151-156.

Sheriif, J.T., Nanda, S.K. and Sajeev, M.S. (2005). Current Status of Cassava Processing Industries in South India. Technical Bulletin No. 42. Central Tuber Crops Research Institute, Sreekariyam, Thiruvananthapuram, Kerala, India.

Sitkey, G. (1986). Mechanics of Agricultural Material. ELSEVIER. Amsterdam.

Widaningsih, R. (2016). Outlook Komoditas Pertanian Tanaman Pangan: Ubi Kayu. Pusat Data dan Sistem Informasi Pertanian Kementerian Pertanian. Jakarta.

Yimmongkol. S. (2009). Research and Development Projects on Improvement of the Potential Use of Dried Cassava Pulp and Cassava Leaf Meal in Concentrate of Feedlot Cattle. Thesis Doctor of Philosophy Agricultural Research and Development. Graduate School, Kasetsart University. 